\title{
Intangible cultural heritage as a motive for choosing the tourist destination Aranđelovac
}

\author{
Nemanja Filipović ${ }^{*}$ \\ ${ }^{1}$ College of Applied technology Science Aranđelovac - CATAR; PhD student, University of \\ Kragujevac, Faculty of Hotel Management and Tourism in Vrnjačka Banja
}

\begin{abstract}
Intangible cultural heritage is of vital importance for the development of a tourist destination. It manifests itself through the customs, celebrations, music, songs, dances, stories, myths, traditions, legends, old crafts, aesthetic, spiritual and social systems of community values. As a value, tourist destinations are presented on the spot as well as at festivals, carnivals, concerts and food service facilities. Culture and tourism are becoming increasingly connected over time and therefore represent an inseparable whole. Interest in culture and cultural programs, among which are also those whose framework pertains to intangible cultural heritage, is constantly increasing. This paper deals with the study of the bond between tourists and intangible cultural heritage of a destination. Namely, the paper argues that the tourists' choice to visit a particular destination depends largely on the intangible cultural heritage in the area of that destination.
\end{abstract}

Keywords: intangible cultural heritage, culture, tourism, destination

JEL classification: Z300

\section{Nematerijalno kulturno nasleđe kao motiv za izbor turističke destinacije Aranđelovac}

Apstrakt: Nematerijalno kulturno nasleđe je od vitalne važnosti za razvoj turističke destinacije. Ispoljava se kroz običaje, praznovanja, muziku, pesmu, igru, priče, mitove, predanja, legende, stare zanate, estetske duhovne i društvene sisteme vrednosti jedne zajednice. Kao vrednost turističke destinacije prezentuju se na licu mesta kao i na festivalima, karnevalima, koncertima, u ugostiteljskim objektima. Kultura i turizam vremenom se sve čvršće povezuju i predstavljaju neraskidivu celinu. Interesovanje za kulturu i kulturne programe, a među njima i one čija je okosnica nematerijalno kulturno nasleđe, u neprestanom je porastu. Ovaj rad se bavi istraživanjem veze između turista i nematerijalnog kulturnog nasleđa destinacije. Naime, rad zastupa stanovište da opredeljenost turista da posete određenu destinaciju pretežno zavisi od nematerijalnog kulturnog nasleđa sa kojim destinacija raspolaže.

Ključne reči: nematerijalno nasleđe, kultura, turizam, destinacija

JEL klasifikacija: Z300

\section{Introduction}

Intangible cultural heritage is becoming increasingly important as a tourist motivation. Tourists are becoming more and more interested in different cultures, performing arts, crafts,

*nemanja.filipovic@vsar.edu.rs 
rituals, gastronomy and interpretations of nature and the universe. The most developed countries in the world promote their cultural heritage for the purpose of tourism development, and devote a great deal of effort in its understanding and promotion.

Intangible cultural heritage consists of intangible cultural assets. It belongs to the oral folk culture which was formed in the remote past and which has been passed down through generations. The tourist offer of a destination predominantly depends on its cultural values and has a great impact on the visitors.

The aim of this research is to investigate the ways and possibilities for the utilization of the intangible cultural heritage potentials at the disposal of the destination, in order to create and improve the tourist offer of the destination. Intangible cultural heritage is considered to be one of the most important and most expansive components of tourism. Thanks to the important historic figures and events from the past, heritage is viewed as part of the cultural tradition of a society. On the other hand, the concept of tourism is a real form of modern consciousness, and it is fundamental and dynamic in its constant interaction with the intangible cultural heritage. Therefore, the concept of tourism based on intangible cultural heritage is invaluable for developing and expanding tourist destinations.

Based on theoretical knowledge and results, international experience and the characteristics of the domestic market, the main objective of this paper is to emphasize the role and importance of the intangible cultural heritage in choosing a tourist destination. In this regard, this paper should also point out the importance of the intangible cultural heritage for the development and creation of a sustainable competitivness of the tourist destination.

The basic goal of the research arises from all of the mentioned above, and it indicates the importance and role of the intangible cultural heritage in the process of development and selection of a tourist destination.

The starting point of this research paper is the basic assumption that the intangible cultural heritage positively influences the choice of a tourist destination. The attractiveness of the destination is conditioned by the offer of intangible cultural heritage. Intangible cultural heritage represents a blend of the modern and traditional. Futhermore, it determines the appearance of a tourist destination, which is available in the selection.

Also, one of the additional assumptions is that the intangible cultural heritage positively influences the higher profitability of the tourist products of Aranđelovac. The image of a nation has a very big impact on visitors since it is directly linked to the tourist offer of the country. Material and spiritual formations and values should be made part of the progress of human society, the creation of a national identity, and therefore a tourist brand as well. Profitability of the tourist product could be significantly improved if the tourist offer were enriched with the intangible cultural heritage.

Last but not the least, it can be concluded that the various contents of intangible cultural heritage are in a positive correlation with the satisfaction of the visitors of Arandjelovac. Namely, the success of the tourist destination results in satisfied visitors.

In the research part of the paper, a statistical method of hypothesis testing will be used. The analysis will be carried out using the Statistical Package for Social Sciences (SPSS).

\section{Culture and tourism}

"Culture is a set of all material and spiritual values (processes, changes, and creations) that have emerged as a consequence of the material and spiritual investment of a man in nature, society and thinking, without which there would be no human society, not even in the simplest form of organization" (Alberti \& Giusti, 2012). Culture represents one of the factors 
of the tourist economy, and that is the part that rests on cultural values or goods as motives for tourist trips. Tourism can be observed from three points of view. First, tourism is a social phenomenon, not a product of activity. Secondly, tourism is the sum of the costs of all travelers or visitors for all their needs, and not just of certain status groups or groups with similar interests, i.e. needs. Thirdly, tourism is a process of experiencing, not of products, but a wealth of different experiences (Rodzi et al., 2013). Therefore, cultural tourism is defined as a specific form of sustainable tourism, or as a visit of tourists who are motivated by their interests in historical, artistic, scientific or craftsmanly products and offer from the local community (Milić, 2014).

However, cultural heritage management is a recent phenomenon (mainly in the last 20 years), whose tendency in many countries has been to concentrate on the heritage "resource" or asset as the central element in manamegent process ( $\mathrm{Du}$ Cros, 2001). Today there is a trend of increasing interest in cultural tourism products in the world. It is anticipated that the cultural tourism market will be one of the five leading segments of the tourism market in the future (Alberti \& Giusti, 2012). The growth of cultural tourism is reflected in the financial indicators. It is estimated that cultural tourists spend one third more than average tourists spend, which is why cultural tourism is ranked among the ten most important and most dynamic tourist branches, and an increasing production of cultural activities influences the increase of its competitiveness (Krasojević \& Đorđević, 2015). Such a growing trend of interest in cultural tourism provides the opportunity for cultural heritage as a resource of development to become sustainable, bringing benefits to the local and wider community, with the precondition for its preservation.

Cultural tourism is becoming an increasingly important form of tourism with multiple positive implications on the socio-economic plan. It provides financial support for the preservation, revitalization and promotion of cultural heritage assets (Krivošejev, 2014). It contributes to the financial and organizational independence of cultural institutions and organizations, as well as the process of decentralization of culture. Cultural tourism has a significant financial effect on the development of the economy of many countries, especially the developing countries. In addition to the material effects of cultural tourism, immaterial effects such as developing awareness and caring for their own cultural values, creating a cultural identity and a positive image of the community are also important. According to UNESCO, the concept of cultural heritage includes several categories (Krasojević \& Đorđević, 2015): Material heritage (movable cultural heritage - paintings, sculptures, manuscripts, coins); Immovable cultural heritage (monuments, archaeological sites) and underwater cultural heritage (ship wrecks, underwater ruins and cities); Intangible cultural heritage (oral tradition, music, dance, rituals, etc.); Natural heritage (natural landscapes with cultural motifs); Legacy of armed conflicts.

A broader view of the structure and content of cultural heritage includes the classification of heritage into tangible and intangible (Herz \& Arnegger, 2016). Within the tangible heritage, there are: military attractions (battlefields, cemeteries, memorials, military buildings, etc.), dark attractions (places of terrorist attacks and mass murders, camps, prisons); historic sites (historical cities, restored coasts, villages, rural settlements), archaeological sites / historical buildings (ancient remains, archaeological sites, castles, churches, historical buildings, museums), industrial attractions (docks, railways, mines, quarries, factories), religious attractions (churches, cathedrals, mountains, rivers, caves, temples, churches). Intangible heritage consists of: art (art tradition, manual skills, diet, gastronomy), language (unique languages, music), national customs (clothes, agricultural methods, religion, behavior, folklore, stories and legends), music and performing arts (dances, music, opera), religion (beliefs, practices and rituals, ceremonies), sport (game, rules and methods), festivals and festivities (ethnical festivals, food festivals, religious ceremonies). 
Modern business requires a change in the tourist product, and therefore a change of a tourist market where cultural heritage becomes one of the elementary factors of attractiveness of tourist destinations. Over the past several years, the interrelationship between tourism and culture has attracted considerable attention and quite rightly become a key point for cultural policy at a regional, national and international level (Isaković, 2016). The border of the destination should be determined by the market, regardless of the administrative boundaries of a specific spatial area visited by tourists (Jovičić, 2013). Today, there is a large number of cultural and historical heritage sites in almost all urban and rural areas.

The term "cultural tourism", which is used interchangeably with the terms "tourism of heritage" or "ethnic tourism", offers tourists the aforementioned attractions of the cultural heritage. In addition to all of the above, the Australian Federal Government describes heritage tourism as "accepting a complete experience that visitors can sense in order to learn what makes a particular destination recognizable - the way of life of the domicile population, the heritage of destination, art, hospitality-and the way of providing services and interpreting cultural heritage (Rodzi et al., 2013). Therefore, the intangible cultural heritage must be the source of emotions for tourists, it must give them a certain experience. Apart from many positive effects of tourism on cultural heritage, there are inevitable negative impacts, too. Tourism can physically negatively affect cultural heritage, so in some destinations tourists are not desirable because they are searching too much for an authentic cultural experience that can open very sensitive sites to a dangerous mass tourism.

Innovative cultural and tourism products enrich the basic product, i.e. the destination brand, increase the consumption, the length of stay of the tourists and the satisfaction with their stay. The result of such movements is the re-visit of tourists, which leads to the stimulation of destination demand, creating opportunities for the development of new market segments (Chhabra et al., 2003). The development of cultural tourism in the future will depend on the quality of cultural resources, but also on their preservation. It can be concluded that culture receives an additional source of income from tourism, markets expand and new market niches are profiled. There is a need for more professional management and promotion of cultural heritage, better control over the use of cultural potentials; a better attitude towards culture is created among the local population, and thus a better image of a tourist destination.

\section{Significance of intangible cultural heritage for the development of a tourist destination}

Modern tourism is characterized by significant quantitative and qualitative changes that manifest themselves in the growth of tourism transportation and the creation of new and more flexible forms of tourism products in which the intangible cultural heritage is becoming more important. Travel movements are a manifestation of personal freedom and the ability of an individual to express his own individual needs and desires, and social interaction is their important characteristic.

While on the move, tourists often temporarily forget many of the social norms that regulate their everyday life and work. Tourists are different from domicile population because they are characterized by different ways of dressing, language and habits, different physiological characteristics. Most often they come from highly-urbanized environments, which means that the interaction that takes place in the destination is between people of different geographical and socio-cultural backgrounds (Jovičić, 2013). Social interaction can be explained more closely by the term of acculturation that characterizes tourism movements. It can be defined as the process of merging and interweaving of the two cultures, which in tourism is reflected in the exchange of cultures of tourists and domicile population in tourist destinations (Jovičić, 2013). 
The development of a tourist destination is important both for the country in which the destination is located as well as for the domicile population. The positive effects of tourism manifest themselves through the inflow of financial means into the country, while the domicile population, by developing a tourist destination, benefits from the employment of tourist workers and the growth of revenues due to the influx of tourists. According to some surveys, $15 \%$ of the tourists' daily spending remains at the disposal of the local population (Nuryanti, 1996).

According to one study dealing with the determinants of tourists' arrivals to the destination, it has been concluded that there are three types of tourist sites: cultural sites, natural beauties and modern tourist places (Rodzi et al., 2013). The main discovery of this survey is that cultural sites (intangible cultural heritage) have a stronger impact on tourists' visits than natural beauties. Ai-Lin-Lee (2010), in her study "Satisfaction of tourists with cultural heritage site", came to the conclusion that there are three important attributes that bring satisfaction to tourists: tourist attraction in general, cultural attraction and heritage, hospitality and diversity. Out of these three attributes, the most important is the cultural attraction and heritage and it is followed by hospitality, and then finally the tourist attraction itself. Based on the above, it can be stated that the cultural heritage is capable of attracting more tourists compared to the tourist attraction itself.

It is evident that the heritage consists of three essential aspects: the diversity of the environment, the life of the domicile population and traditional art, folklore, and so on. If the tourist destination were to be compared with a man as a social being, the tourist destination without these three aspects would be like a man without a soul (Rodzi et al., 2013). Intangible values have been converted into a tourism product that is exchanged on the market to meet the needs of tourists. This process uses the authenticity of culture to achieve economic and commercial effects.

On the basis of conducted research and studies as well as opinions of theoreticians in this field it can be concluded that the intangible heritage is an important factor for the formation of a tourist destination, a factor of development as well as an inevitable component of the development policy of the tourist destination.

\section{Intangible heritage and choice of a tourist destination}

An important part of the national and cultural identity of Serbia is a rich cultural and historical heritage and intangible cultural heritage reflected in oral tradition, customs, festivals, artistic expressions and traditional crafts. The establishment of the national and tourist brand of Serbia implies the use of all those elements that have positive effects on creating a comprehensive picture of Serbia as an attractive area (Bjeljac et al., 2015). In order to understand the connection between the intangible cultural heritage and the choice of the tourist destination, a survey was conducted so as to examine the impact of intangible cultural heritage as one of the motives for choosing Aranđelovac for a tourist destination. Survey of the respondents was conducted in the period August - September 2017 on the territory of Aranđelovac. The total of 161 respondents were surveyed by a simple random sample. Using the statistical software package for social sciences, the steps of the analysis that was carried out will be presented in the further text.

On the basis of the conducted survey, the sample structure shows that $56 \%$ of the respondents are men, while $44 \%$ of the respondents are women. Graph 2 shows the structure of the sample according to age, where the most numerous respondents are aged 16 to 30 and they make $48 \%$, respondents aged 31 to 50 make $44 \%$ of the total sample, $7 \%$ of the respondents are over 50 years of age, $1 \%$ of respondents under the age of 15 . 
Figure 1: Structure by gender

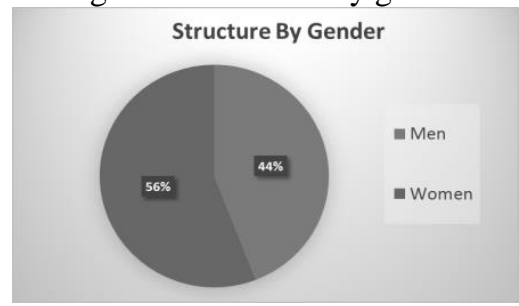

Figure 2: Structure by age

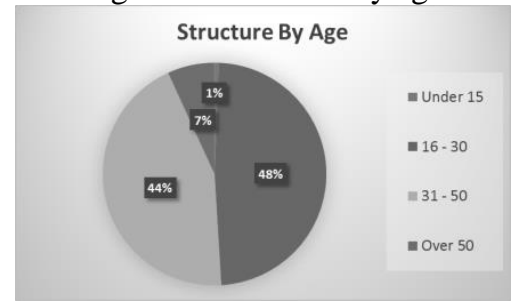

The structure of the sample according to profession is made up of $57 \%$ of employed respondents, $32 \%$ are students, $7 \%$ are unemployed, $3 \%$ are pensioners, while $1 \%$ are pupils. In terms of their education, $52 \%$ are those with completed higher education, $19 \%$ with secondary education, $18 \%$ have completed master's studies, $9 \%$ have a doctoral or master's degree, while $2 \%$ have completed primary education.

Figure 3: Structure according to occupation

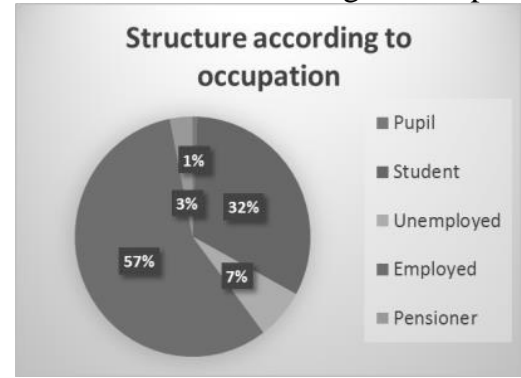

Figure 4: Structure according to education

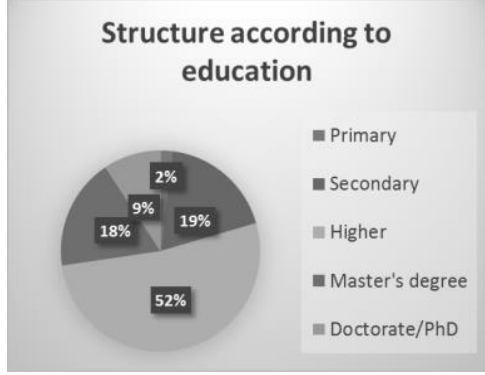

Examination of the interdependence between the intangible cultural heritage and profitability

Table 1: Correlation analysis

\begin{tabular}{|c|c|c|c|c|}
\hline & $\begin{array}{c}\text { Intangible } \\
\text { heritage }\end{array}$ & $\begin{array}{c}\text { Other } \\
\text { motives }\end{array}$ & Profitability & Satisfaction \\
\hline Intangible heritage & 1 & $0.561^{* *}$ & $0.709^{* *}$ & $0.522^{* *}$ \\
\hline Other motives & $0.561^{* *}$ & 1 & $0.360^{* *}$ & $0.388^{* *}$ \\
\hline Profitability & $0.709^{* *}$ & $0.360^{* *}$ & 1 & $0.526^{* *}$ \\
\hline Satisfaction & $0.522^{* *}$ & $0.388^{* *}$ & $0.526^{* *}$ & 1 \\
\hline
\end{tabular}

** All correlation coefficients are significant at the level 0.01

Based on the results of the correlation analysis, it can be seen that the values of the Pearson coefficient (Pearson) are significant at the level of 0.01 , respectively correlations are statistically significant with a probability of $99 \%$. The highest value of the Pearson coefficient is present between Intangible Heritage and Profitability and is 0.709. By looking at the results in Table 1, a strong linear correlation between intangible heritage and profitability is evident. Consequently, the established statistical linear correlation means that the intangible cultural heritage positively influences the higher profitability of the tourism product of the destination.

Examination of the impact of intangible cultural heritage on tourist satisfaction

Table 2: Simple regression analysis

\begin{tabular}{|c|c|c|c|c|}
\hline Variables & $\mathrm{R}^{2}$ & $\mathrm{~F}$ & $\beta$ & $\mathrm{t}$ \\
\hline Intangible Heritage & 0,273 & 59,624 & 0,522 & $7,722 * *$ \\
\hline Other motives & 0,150 & 28,153 & 0,388 & $5,306^{* *}$ \\
\hline
\end{tabular}

$* *$ The value is significant at the level $r<0.01$ 
The obtained values based on the simple regression analysis are statistically significant at the level of 0.01 and with a probability of $99 \%$. The determination coefficient for the variable Intangible Heritage is 0.273 , which means that $27.3 \%$ of the variability of satisfaction is described by the regression model, and $72.7 \%$ is under the influence of a factor that does not contain the regression model. Observing other motives of coming to Arandjelovac, according to the obtained regression research, they do not have a major influence on the satisfaction of the tourists, since $15 \%$ of the variability is described by the regression model. Based on these results, it can be concluded that intangible heritage and other motives to visit do not have a significant impact on the satisfaction of tourists. This contravened the hypothesis that the different contents of the intangible cultural heritage are in a positive correlation with the satisfaction of the visitors of Aranđelovac.

\section{Multiple regression analysis}

Table 3: Results of multiple regression analysis

\begin{tabular}{|c|c|c|c|}
\hline Variables & $\mathrm{B}$ & $\mathrm{t}$ & $\mathrm{Sig}$ \\
\hline Intangible Heritage & 0,205 & 1,968 & 0,05 \\
\hline Other motives & 0,156 & 1,984 & $0,049 *$ \\
\hline
\end{tabular}

$* *$ The value is significant at the value $\mathrm{r}<0.01 * \mathrm{r}<0.05$

$\mathrm{R}^{2}=0.338 \mathrm{~F}=26.733 \mathrm{p}<0.01$

The value of the coefficient of determination is 0.338 , which means that $33.8 \%$ of the variability of satisfaction is described by the regression model, while $66.2 \%$ is under the influence of a factor that does not contain the regression model. Observing values from the columns $\beta$ and Sig, it can be seen that the intangible heritage has no statistically significant effect on the satisfaction of tourists.

\section{Parameter T test for two independent samples}

Table 4: Results of parameter $\mathrm{T}$ test

\begin{tabular}{|c|c|c|c|c|c|c|}
\hline \multirow{2}{*}{ Statements } & \multicolumn{2}{|c|}{ Men } & \multicolumn{2}{|c|}{ Women } & \multirow{2}{*}{$\mathrm{T}$ value } & \multirow{2}{*}{$\begin{array}{l}\text { Impor } \\
\text { tance }\end{array}$} \\
\hline & AS & SD & AS & SD & & \\
\hline $\begin{array}{l}\text { 1. Natural attractions can serve as a } \\
\text { motive for your visit }\end{array}$ & 4,58 & 0,921 & 4,46 & 0,781 & 0,908 & 0,365 \\
\hline $\begin{array}{l}\text { 2.Cultural attractions of Aranđelovac } \\
\text { are a significant motive for the visit }\end{array}$ & 4,45 & 0,891 & 4,14 & 0,989 & 2,037 & 0,043 \\
\hline $\begin{array}{l}\text { 3.The history of Aranđelovac/ } \\
\text { tradition can be crucial when } \\
\text { deciding to visit it }\end{array}$ & 4,24 & 1,088 & 4,06 & 1,105 & 1,055 & 0,293 \\
\hline $\begin{array}{l}\text { 4.Sports and recreational offer can be } \\
\text { an important motive for visiting } \\
\text { Aranđelovac }\end{array}$ & 3,37 & 1,334 & 3,52 & 1,163 & $-0,779$ & 0,430 \\
\hline $\begin{array}{l}\text { 5.Aranđelovac is most often visited } \\
\text { because of healthcare / wellness \& } \\
\text { spa programmes }\end{array}$ & 2,93 & 1,356 & 3,06 & 1,239 & $-0,608$ & 0,540 \\
\hline $\begin{array}{l}\text { 6.Gastronomic offer has an important } \\
\text { role in selecting Aranđelovac as a } \\
\text { tourist destination }\end{array}$ & 4,01 & 1,189 & 3,43 & 1,218 & 3,035 & 0,003 \\
\hline $\begin{array}{l}\text { 7.Aranđelovac is most often visited } \\
\text { for manifestations, concerts or other } \\
\text { events }\end{array}$ & 3,38 & 1,324 & 3,18 & 1,223 & 1,006 & 0,316 \\
\hline
\end{tabular}




\begin{tabular}{|l|l|l|l|l|l|l|}
\hline $\begin{array}{l}\text { 8.Entertainment and nightlife affect } \\
\text { the choice of tourist destination }\end{array}$ & 3,87 & 1,264 & 3,47 & 1,326 & 1,972 & 0,050 \\
\hline $\begin{array}{l}\text { 9.Visit to relatives or friends is a } \\
\text { frequent motive for coming to } \\
\text { Arandjelovac }\end{array}$ & 3,58 & 1,509 & 3,60 & 1,444 & $-0,096$ & 0,923 \\
\hline $\begin{array}{l}\text { 10.Religious needs influence the } \\
\text { choice of a tourist destination }\end{array}$ & 3,32 & 1,529 & 2,76 & 1,310 & 2,539 & 0,014 \\
\hline $\begin{array}{l}\text { 11.Learning about cultural heritage } \\
\text { can influence the choice of } \\
\text { Aranđelovac }\end{array}$ & 4,10 & 1,071 & 3,89 & 1,086 & 1,224 & 0,223 \\
\hline $\begin{array}{l}\text { 12.Aranđelovac's artistic tradition } \\
\text { can be crucial when deciding on a } \\
\text { visit }\end{array}$ & 4,08 & 1,052 & 3,77 & 0,995 & 1,962 & 0,051 \\
\hline $\begin{array}{l}\text { 13.You think that intangible cultural } \\
\text { heritage initiates your frequent visits } \\
\text { to Aranđelovac }\end{array}$ & 3,92 & 1,180 & 3,52 & 1,073 & 2,209 & 0,029 \\
\hline $\begin{array}{l}\text { 14.You think that you spend enough } \\
\text { money on getting to know the } \\
\text { intangible heritage }\end{array}$ & 3,61 & 1,248 & 3,12 & 1,150 & 2,551 & 0,012 \\
\hline $\begin{array}{l}\text { 15.Elements of supply of intangible } \\
\text { heritage are affordable in price }\end{array}$ & 3,97 & 1,069 & 3,77 & 1,039 & 1,228 & 0,221 \\
\hline $\begin{array}{l}\text { 16.The relationship between service } \\
\text { quality and prices is very favorable }\end{array}$ & 4,03 & 1,042 & 3,84 & 0,911 & 1,193 & 0,235 \\
\hline $\begin{array}{l}\text { 17.The hospitality of the hosts is } \\
\text { crucial for subsequent visits to } \\
\text { Aranđelovac }\end{array}$ & 4,32 & 0,997 & 4,33 & 0,899 & $-0,062$ & 0,950 \\
\hline $\begin{array}{l}\text { 18.You are very satisfied with the } \\
\text { whole tourist offer of Aranđelovac }\end{array}$ & 3,79 & 1,286 & 3,62 & 0,978 & 0,933 & 0,368 \\
\hline $\begin{array}{l}\text { 19.You would recommend your } \\
\text { friends to visit Aranđelovac }\end{array}$ & 4,28 & 0,974 & 4,47 & 0,737 & $-1,328$ & 0,186 \\
\hline
\end{tabular}

Observing the motives that determine the choice of a tourist destination by parametric $\mathrm{T}$ test for two independent samples, there have been significant differences in attitudes between men and women. On the basis of the higher value of the arithmetic mean, where the value of $\mathrm{T}$ is positive, in comparison with women, the men gave higher grades for the following motives that influence the choice of a tourist destination: Cultural attractions Aranđelovac, Gastronomic offer, Entertainment and night life, Religion and artistic tradition of Aranđelovac. The research has shown differences in attitudes of men and women to the statement "You consider that the intangible cultural heritage initiates your frequent visits to Aranđelovac", where higher grades were given by men whose arithmetic mean is 3.92 , while the significance is at the level of 0.05 . Therefore, it can be noted that elements of intangible heritage positively influence the choice of a tourist destination.

ANOVA test

Table 5: ANOVA test results

\begin{tabular}{|c|c|c|}
\hline Variables & F & Sig \\
\hline Intangible Heritage & $2,642 *$ & 0,036 \\
\hline Other motives & 1,402 & 0,236 \\
\hline Satisfaction & 1,740 & 0,144 \\
\hline
\end{tabular}


Based on the results of the ANOVA test, we see that there are differences in assessments according to given variables in respondents of different degrees of education. Differences exist with the variable Intangible Heritage where the Sig value is 0.036, which is less than 0.05 , so the value is significant with a probability of $95 \%$. In other variables, we see that Sig values are greater than 0.05 , so we can conclude that there are no differences in assessments according to different categories of education in the variable Other motives and Satisfaction.

This statistical analysis has proven the starting hypothesis of research that the intangible cultural heritage positively influences the choice of a tourist destination. Also, statistical data processing has proven that intangible cultural heritage affects the higher profitability of the tourist destination product. Namely, there is a strong linear correlation between intangible heritage and profitability. The analysis disproved the hypothesis that the various contents of the intangible cultural heritage are in a positive correlation with the satisfaction of the visitors of Aranđelovac.

\section{Conclusion}

All material and intangible, natural or cultural assets as factors of the spatial culturalhistorical units represent tourist resources and can be used for tourist purposes. They can also produce economic performance and contribute to the economic development of a particular destination. Cultural resources can become tourist resources only by design planning.

The essence of a cultural intangible product in tourism is its interpretation that should enable tourists to experience culture in the past and present. Tourists are increasingly interested in different cultures, performing arts, crafts, rituals, gastronomy and interpretations of nature and the universe. There is an increasing awareness of the importance of cultural interaction which encourages dialogue, builds understanding and improves tolerance. Oral folk culture which was formed in the remote past has been passed down through generations. The main principles of oral culture are continual preservation and the obligation to pass the heritage to younger generations. Oral traditional culture consists of customs, rituals, beliefs, music, skills, crafts, oral literature. The research has shown that the intangible cultural heritage positively influences the choice of a tourist destination. It is evident that the intangible cultural heritage contributes to the higher profitability of the tourism product of the destination. It was concluded by testing that different contents of intangible cultural heritage are not in a positive correlation with the satisfaction of the visitors of Aranđelovac.

\section{References}

1. Alberti, F. G. \& Giusti, J. D. (2012). Cultural heritage, tourism and regional competitiveness: the motor valley cluster. City, Culture and Society, 3, 261-273.

2. Bjeljac, Ž., Terzić, A. \& Lović, L. (2015). Nematerijalno kulturno nasleđe u Srbiji kao turistički brend [Intangible cultural haritage in Serbia as a tourist brand]. Geografski institut „Jovan Cvijić“, SANU, 15, 53-61. https://doi.org/10.5937/TurPos1515053B

3. Chhabra, D., Healy, R. \& Sills, E. (2003). Staged authenticity and heritage tourism. Annals of Tourism Research, 30(3), 702-719. https://doi.org/10.1016/S01607383(03)00044-6

4. Du Cros, H. (2001). A New Model to Assist in Planning for Sustainable Cultural Heritage. International Journal of Tourism Research, 3, 165-170. https://doi.org/10.1002/jtr.297

5. Herz, M. \& Arnegger, J. (2016). Economic and destination image impacts of megaevents in emerging tourist destinations. Journal of Destination Marketing \& Management, 76-85. https://doi.org/10.1016/j.jdmm.2015.11.007 
6. Isaković, S. (2016). Umetničke prakse u kontekstu kulturnog turizma [Artistic practices in the context of cultural touris]. Vrnjačka Banja: Fakultet za hotelijerstvo i turizam u Vrnjačkoj Banji.

7. Jovičić, D. (2013). Menadžment turističkih destinacija [Management of tourist destination]. Beograd: Geografski fakultet.

8. Krasojević, B. \& Đorđević, B. (2015). Nematerijalno kulturno nasleđe: turistički resurs Srbije [Intangible cultural haritage: touristic resource of Serbia]. International Scientific Conference of IT and Business-Related Research (pp. 561-565).

9. Krivošejev, V. (2014). Upravljanje baštinom i održivi turizam [Heritage management and sustainable tourism]. Valjevo: Narodni muzej.

10. Lee, A. L. (2010). Tourist Satisfaction with Cultural Heritage Site - A Case study of the Malacca State. Retrieved January 12, 2017, from

http://etd.lib.nsysu.edu.tw/ETD-db/ETD-search/view_etd?URN=etd-0816110-141610

11. Milić, V. (2014). Kulturno istorijsko nasleđe gradske opštine Savski venac kao osnova za razvoj turizma [Cultural and historic heritage of the municipality of Savski Venac as the base for the tourism development]. Menadžment u hotelijerstvu $i$ turizmu, 2(2), 85-94.

12. Nuryanti, W. (1996). Heritage and postmodern tourism. Annals of Tourism Research, 23(2), 249-260.

https://doi.org/10.1016/0160-7383(95)00062-3

13. Rodzi, M. N. I, Zaki, S. A. \& Subli, S. H. M. S. (2013). Between Tourism and Intangible Cultural Heritage. AcE-Bs Hanoi ASEAN Conference on EnvironmentBehaviour Studies "Cultural Sustainability in the Built and Natural Environment". Hanoi, Vietnam: Hanoi Architectural University. 